\title{
THERAPEUTIC EFFICACY OF ALPHA LIPOIC ACID IN COMBINATION WITH SUCCIMER AGAINST LEAD-INDUCED OXIDATIVE STRESS, HEPATOTOXICITY AND NEPHROTOXICITY IN RATS
}

\author{
Khaled M. Abdel Aal ${ }^{*}$ and Abeer M.R. Hussein ${ }^{* * *}$ \\ Departments of *Forensic Medicine \& Clinical Toxicology and **Pharmacology \\ Faculty of Medicine, Assiut University
}

\begin{abstract}
:
Lead toxicity is a worldwide health problem due to continuous exposure of the population to lead in the environment especially workers in industries. It affects many body organs especially the liver and kidneys. The aim of this study is to investigate and compare the therapeutic potential of alpha lipoic acid (ALA) when it is administrated alone and in combination with succimer or dimercaptosuccinic acid (DMSA) against lead induced oxidative stress, hepatotoxicity and nephrotoxicity. Seventy five healthy male albino rats were used divided into 5 equal groups. Group (1) the control group was administrated distilled water orally for 6 weeks. Group (II) rats were given lead acetate (0.2\%) in drinking water for 5 weeks and distilled water only orally during the $6^{\text {th }}$ week . Group (III, IV and V) rats were given lead acetate $(0.2 \%)$ in drinking water for 5 weeks followed by DMSA in a dose of $20 \mathrm{mg} / \mathrm{kg}$ body weigh/day intraperitoneally (i.p.) alone, ALA in a dose of $25 \mathrm{mg} / \mathrm{kg}$ body weigh/day (i.p.) alone and both drugs in combination during the $6^{\text {th }}$ week only respectively. Rats were sacrificed after six weeks. Blood lead level, serum lipid peroxides (TBARS), serum total antioxidant (TAO) and serum nitric oxide (NO) levels were measured. Also Liver function tests (serum alkaline phosphatase, glutamic oxalacetic transaminase and glutamaic pyruvic transaminase) were measured. In addition, kidney function tests (serum urea, creatinine and uric acid) were done. Results showed an increase in the mean of blood lead level, increase serum TBARS levels, decrease serum TAO and NO levels and increase levels of liver and kidney function tests in lead treated group. Treatment with DMSA alone resulted in reduction of blood lead levels, improvement of serum NO level but not decrease serum TBARS level and moderate decrease in the elevated liver and kidney function test parameters. Rats treated with ALA alone showed no reduction in the elevated blood lead levels, but decreased serum TBARS and improved serum NO, TAO levels, liver and kidney function tests. Rats treated with DMSA and ALA concurrently showed decrease in blood lead levels, decrease serum TBARS, increase serum NO and TAO levels to near normal level and corrected liver and kidney function tests. In conclusion administration of ALA has beneficial effect as thiolmediated antioxidant function when given to occupationally exposed workers to lead and during treatment of lead poisoning with DMSA as it increases its efficacy.
\end{abstract}

\section{INTRODUCTION:}

Exposure to lead continues to be a widespread problem in many countries. Lead is one of the most widely used metals in industries. Batteries, paints and pigments, plastic, ceramic, secondary foundries and welding being the most important occupational setting. The general population may get exposed to lead due to food and water contamination and air pollution caused by industrial emission and gasoline containing lead compounds (Ercal et al., 1996). 
Approximately $90 \%$ of the total body lead is contained within bones. Blood lead accounts for $4 \%$ and the remaining lead residues in the liver and kidneys (Boeckx, 1986). The liver and kidneys are also known to play a major role in the elimination of lead (Goyer and Chirian, 1979) and hence accounts for the toxic action (Lockitch, 1993).

Considering the multiplicity of lead interactions with and effects on different systems, it is likely that several independent mechanisms are involved. Oxidative stress associated with the presence of lead in mammalian tissues and organs (predominately blood, liver, brain and kidneys) appears to be one possible molecular mechanism for lead toxicity (Lima-Hermes et al., 1991 \& Gurer and Ercal, 2000).

Lead-induced disruption of the prooxidant/antioxidant balance in lead burdened tissues could contribute to tissue injury via oxidative damage to critical biomolecules (i.e., lipids, proteins and DNA). Significant accumulations of malondialdehyde (MDA), a byproduct of lipid peroxidation, and depletion of reduced glutathione have been observed in both lead-exposed in vitro and in vivo systems (Spitz et al., 1991).

Lead causes oxidative stress leads to free radical damage via; the generation of reactive oxygen species (ROS); hydroperoxides, singlet oxygen and hydrogen peroxide. In addition to the direct depletion of antioxidant defense system of cells (Adonaylo et al., 1999 and Ercal et al., 2001).

Lipoic acid (LA) and its reduced form, dihydrolipoic acid (DHLA), have gained considerable attention due to their roles as biological thiol antioxidants. ALA readily crosses the blood- brain barrier and is a "metabolic antioxidant"; i.e., it is accepted by human cells as substrate and is reduced to
DHLA. Unlike ascorbic acid, DHLA is not destroyed by quenching free radicals, but rather can be recycled from LA. Moreover, LA and DHLA are amphipathic molecules and may act as antioxidants both in hydrophilic and lipophilic environments (Moini et al., 2002).

Succimer or Dimercaptosuccinic acid (DMSA) is an orally active, metal chelating agent with two sulfhydryl (SH) groups that forms stable water-soluble complexes with lead (Miller, 1998). In addition DMSA as a thiolcontaining compound has potential antioxidant activity protecting against lead induced oxidative damage (Gurer et al., 1998).

The objective of the present study was to investigate the combined therapeutic potentials of ALA and DMSA on some biochemical parameters of lead induced oxidative stress, hepatotoxicity and nephrotoxicity in male albino rats through: (1) Blood lead level (2) Oxidative stress indices as serum TBARS, TAO and NO levels (3) liver function tests (4) kidney function tests.

\section{MATERIALS AND METHODS:}

\section{1-Chemicals:}

Alpha Lipoic acid, meso-2,3dimercaptosuccinic acid and lead acetate were purchased from Sigma Chemical Co., St. Louis, MO, USA. DMSA was prepared immediately before use to a concentration of $57 \mathrm{mM}$ in $5 \%$ (w/v) NaHCO3. Lead acetate as a powder was dissolved in double distilled water prior to use. All other chemicals and solvents were used of highest purity and analytical grade.

\section{2-Animals and experimental design:}

Healthy adult male albino rats obtained from Animal House of Faculty of Medicine, Assiut University, weighing 220-250 gm were used in the study. The rats were fed with a 
standard rat diet and had free access to water. The rats were housed under standard conditions of humidity and controlled temperature (20$26^{\circ} \mathrm{C}$ ) with 12 hs light and 12 hs dark exposure.

\section{Experimental design:}

Seventy five adult male albino rats were used. The rats were assigned into five groups, fifteen rats on each group:

Group I: (control) received distilled water orally for 6 weeks.

Group II: received lead acetate $(0.2 \%)$ in drinking water for 5 weeks and distilled water orally during week 6 only.

Group III: received lead acetate $(0.2 \%)$ in drinking water for 5 weeks and DMSA (20 $\mathrm{mg} / \mathrm{kg}$ body weight/day i.p.) during week 6 only.

Group IV: received lead acetate $(0.2 \%)$ in drinking water for 5 weeks and ALA $(25 \mathrm{mg} / \mathrm{kg}$ body weight/day i.p.) during week 6 only.

-Group V: received ALA (25 $\mathrm{mg} / \mathrm{kg}$ body weight/day i.p.) plus DMSA (20 $\mathrm{mg} / \mathrm{kg}$ body weight/day i.p.) during week 6 only.

Solutions were prepared fresh daily. Dosing regime for the test animals were fixed and rats were sacrificed 24 hours from the last dose based on Sivaprasad et al., (2004a).

\section{3-Blood samples collection:}

Blood samples were collected from the orbital sinus of rats. One blood samples taken on EDTA containing tubes for estimation of blood lead level. Other samples were taken in glass tubes for collection of sera after centrifugation for estimation of other biochemical parameters.

\section{4- Biochemical measurements:}

\section{A- Blood Lead level:}

It was estimated using an atomic absorption spectrophotometer/flame emission spectrophotometer (Shimadzu- model AA-630-02Japan) using an air acetylene flame and hollow cathode lamp. The wave length was adjusted to $283.3 \mathrm{~nm}$ and the used current was $6 \mathrm{~mA}$. It was expressed as $\mu \mathrm{g} / \mathrm{dl}$ (Delpour et al., 1999).

B-Measurement of serum level of Malondialhyde (MDA) or thiobarbituric acid reactive substances (TBARS):

Malondialhyde (MDA) formed during lipid peroxidation can react with thiobarbituric acid to generate color product. It is determined calorimetrically as thiobarbituric acid reactive substances (TBARS) using spectrophotometer. The TBARS level in samples was calculated from the standard curve and was expressed as $\mathrm{nmol} / \mathrm{ml}$ according to the method of described by Thayer, (1984).

\section{C-Measurement of serum level of total antioxidants (TAO):}

The serum TAO level was measured enzymatically by spectrophotometer. The TAO level was calculated from the standard curve and expressed as $\mathrm{mmol} / \mathrm{l}$ according to the method described by Miller et al. (1993).

\section{D-Measurement of serum level of nitric oxide (NO):}

Nitric oxide (NO) was measured in the serum by assaying nitrate, one of the stable and non volatile end-products of NO oxidation. Serum nitrate concentration was measured using Griess reagents using spectrophotometer. The total NO level in samples was calculated from the standard curve and expressed as $\mu \mathrm{mol} / \mathrm{ml}$ as described by Green et al. (1982).

E-Assessment of liver function tests: 
Measurement of liver function tests by spectrophotometer using colorimetric diagnostic kits (Diagnostics Co., Giza, Egypt).

-Serum alkaline phosphatase (ALP) level was measured according to Tietz and Rinker (1983).

-Glutamic oxalacetic transaminase (GOT) was measured according to Reitman and Frankel (1957).

-Glutamaic pyruvic transaminase (GPT) was measured according to Reitman and Frankel (1957).

\section{F-Assessment of renal function tests:}

Measurement of renal function tests creatinine and uric acid using standard diagnostic kits by spectrophotometer using colorometric diagnostic kits (Biodiagnostic, Giza, Egypt).

-Serum urea was measured according to Coulombe and Favreau, (1963).

-Serum ceatinine was measured according to Larsen (1972).

-Serum uric acid was measured according to Whitehead et al. (1991).

\section{5- Statistical Analysis:}

Statistical analysis was done using one way analysis of variance (ANOVA) was done to compare between the control and other treated groups, followed by post-hoc analysis (Dunnett's test) using SPSS computer program. The data were presented in the form of mean \pm standard error (SE). When only two groups were compared, Student's t-test was used. The difference was insignificant at $p>0.05$, significant at $\mathrm{P}<0.05$ and highly significant at $\mathbf{P}<0.01$.

\section{RESULTS:}

\section{1-Lead concentration in blood:}

The mean of blood lead level was highly significantly increased in lead treated group (35.9 \pm 2.6$)$ as compared to control group (1.027 $\pm 0.24)$. There was a highly significant decrease in the mean of blood lead level on treatment with DMSA $(14.9 \pm 1.17)$ alone and when combined with ALA (9.81 \pm 0.9$)$. There was no significant decrease in ALA treated group when compared to lead treated group as shown in table (1).

\section{2-Serum lipid peroxidation (TBARS) level:}

The mean of TBARS level was a highly significantly increased in lead treated group $(0.923 \pm 0.09)$ as compared to control group $(0.355 \pm 0.024)$.

There was a highly significant decrease in the mean of serum TBARS level in treatment with ALA alone $(0.475 \pm 0.037)$ and when it combined with DMSA $(0.427 \pm 0.032)$. There was insignificant decrease in TBARS level in DMSA treated group $(0.851 \pm 0.078)$ when compared to lead treated group $(0.923 \pm 0.09)$ as shown in table (2).

\section{3-Serum total antioxidants (TAO) level:}

There was a highly significant decrease in the mean of serum TAO level in lead treated group $(0.924 \pm 0.081)$ compared to control group $(\mathbf{1 . 8 8} \pm 0.1)$. There was a significant increase in TAO level in treatment with DMSA (1.327士 0.097) while, a highly significant increase in the mean of serum TAO level in treatment with ALA (1.74 \pm 0.092$)$ alone and in combination with DMSA $(1.82 \pm 0.098)$ when compared with lead treated group $(0.924 \pm 0.081)$ as shown in table (3).

4-Serum nitric oxide (NO) level: 
The mean of serum NO level was highly significant decreased in lead treated group (18.9 $\pm 1.66)$ as compared to control group $(26.7 \pm 2.2)$.

There was a highly significant increase in serum NO level to near control level in treatment with DMSA (24.3 \pm 1.93$)$, ALA $(23.8 \pm 1.85)$ and DMSA when combined with ALA (25.6 \pm 2.11$)$ when compared to lead treated group (18.9 \pm 1.66$)$ as shown in table (4).

\section{5-Liver function tests:}

The mean of serum levels of ALP, GOT and GPT were highly significantly increased in lead treated group $(223.9 \pm 17.56),(145.1 \pm 11.63)$ and (125.1 \pm 6.72$)$ respectively as compared to control group $(146.6 \pm 5.5),(61.5 \pm 3.9)$ and $(50.8 \pm 3.32)$ respectively.

There was a significant decrease in the elevated serum level of ALP, GOT and GPT in treatment with DMSA (176.9 \pm 11.77$),(106.7 \pm$ 9.93) and $(95.33 \pm 8.21)$ respectively and on treatment with ALA $(180.7 \pm 10.02),(109.2 \pm 7.04)$ and $(100.2 \pm 8.24)$ respectively. There were a highly significant decrease in the elevated serum level of ALP, GOT and GPT when ALA and
DMSA given in combination $(148.4 \pm 6.2),(66.80$ $\pm 4.81)$ and $(60.91 \pm 4.46)$ respectively when compared with lead treated group as shown in table (5).

\section{6-Kidney function tests:}

The mean of serum levels of urea, creatinine and uric acid were highly significantly increase in lead treated group $(53.82 \pm 4.56),(0.554 \pm$ $\mathbf{0 . 0 4 4 )}$ and $(\mathbf{7 . 8 7 5} \pm 0.48)$ respectively when compared to control group $(24.7 \pm 1.5),(0.351 \pm$ $0.01)$ and $(4.92 \pm 0.25)$ respectively.

There were significant decrease in the mean of serum urea, creatinine and uric acid levels on treatment with DMSA $(38.31 \pm 3.692),(0.417 \pm$ $0.016)$ and $(5.986 \pm 0.49)$ respectively and on treatment with ALA $(40.64 \pm 3.75),(0.433 \pm 0.037)$ and $(6.175 \pm 0.46)$ respectively. A highly significant decrease in the elevated serum level of urea, creatinine and uric acid was found in combination of DMSA with ALA treated group (28.82 \pm 2.43$), \quad(0.356 \pm 0.014)$ and $(5.1 \pm 0.25)$ respectively when compared with lead treated group as shown in table (6).

Table (1): Blood lead level in different rat groups

\begin{tabular}{|c|c|}
\hline Groups & $\begin{array}{c}\text { Blood lead level }(\mu \mathrm{g} / \mathrm{dl}) \\
(\text { Mean } \pm \mathrm{SE})\end{array}$ \\
\hline G.1: control & $1.027 \pm 0.24$ \\
\hline G.2: lead only & $35.9 \pm 2.6^{\circ \bullet}$ \\
\hline G.3: lead + DMSA & $14.9 \pm 1.17 * *$ \\
\hline G.4: lead + ALA & $34.8 \pm 2.06$ \\
\hline G.5: lead + DMSA + ALA & $9.81 \pm 0.9 * *$ \\
\hline
\end{tabular}


Table (2): Serum lipid peroxidation (TBARS) level (nmol/ml) in different rat groups

\begin{tabular}{|c|c|}
\hline Groups & $\begin{array}{c}\text { Serum TBARS (nmol/ml) } \\
(\text { Mean } \pm \text { SE) }\end{array}$ \\
\hline G.1: control & $0.355 \pm 0.024$ \\
\hline G.2: lead only & $0.923 \pm 0.09^{\bullet \bullet}$ \\
\hline G.3: lead + DMSA & $0.851 \pm 0.078$ \\
\hline G.4: lead + ALA & $0.475 \pm 0.037 * *$ \\
\hline G.5: lead + DMSA + ALA & $0.427 \pm 0.032 * *$ \\
\hline
\end{tabular}

$\bullet \bullet$ Highly significant at $\mathrm{P}<0.001$ compared to control (t- test).

** Highly significant at $\mathbf{P}<0.001$ compared to lead treated group (ANOVA).

Table (3): Serum total antioxidants (TAO) level in different rat groups

\begin{tabular}{|c|c|}
\hline Groups & $\begin{array}{c}\text { Serum TAO }(\mathrm{mmol} / \mathrm{l}) \\
(\text { Mean } \pm \text { SE })\end{array}$ \\
\hline G.1: control & $1.88 \pm 0.1$ \\
\hline G.2: Lead only & $0.924 \pm 0.081^{\bullet \bullet}$ \\
\hline G.3: Lead + DMSA & $1.327 \pm 0.097 *$ \\
\hline G.4:Lead + ALA & $1.74 \pm 0.092 * *$ \\
\hline G.5: Lead + DMSA + ALA & $1.82 \pm 0.098 * *$ \\
\hline
\end{tabular}

$\bullet$ Highly significant at $P<0.001$ compared to control (t- test).

* A significant at $\mathrm{P}<0.05$ compared to lead treated group (ANOVA).

** Highly significant at $\mathbf{P}<0.001$ compared to lead treated group (ANOVA).

Table (4): Serum nitric oxide (NO) level ( $\mu \mathrm{mol} / \mathrm{L})$ in different rat groups

\begin{tabular}{||l|c||}
\hline \multicolumn{1}{|c|}{ Groups } & Serum NO $(\mu \mathrm{mol} / \mathrm{L})$ \\
G.1: control & $($ Mean \pm SE) \\
G.2: lead only & $26.7 \pm 2.2$ \\
G.3: lead + DMSA & $18.9 \pm 1.66^{\circ *}$ \\
G.4: lead + ALA & $24.3 \pm 1.93^{* *}$ \\
G.5: lead + DMSA + ALA & $23.8 \pm 1.85^{* *}$ \\
\hline
\end{tabular}

••Highly significant at $P<0.001$ compared to control (t- test).

** Highly significant at $\mathbf{P}<0.001$ compared to lead treated group (ANOVA).

Table (5): Serum liver function tests in different rat groups

\begin{tabular}{|c|c|c|c|}
\hline Groups & $\begin{array}{l}\text { ALP (IU/I) } \\
(\text { Mean } \pm \text { SE) }\end{array}$ & $\begin{array}{l}\text { GOT (IU/l) } \\
(\text { Mean } \pm \text { SE) }\end{array}$ & $\begin{array}{l}\text { GPT (IU/I) } \\
(\text { Mean } \pm \text { SE) }\end{array}$ \\
\hline G.1: control & $146.6 \pm 5.5$ & $61.5 \pm 3.9$ & $50.8 \pm 3.32$ \\
\hline G.2: lead only & $223.9 \pm 17.56^{\circ \bullet}$ & $145.1 \pm 11.63^{\circ \bullet}$ & $125.1 \pm 6.726^{\circ \bullet}$ \\
\hline G.3: lead + DMSA & $176.9 \pm 11.77 *$ & $106.7 \pm 9.93 *$ & $95.33 \pm 8.214 *$ \\
\hline G.4: lead + ALA & $180.7 \pm 10.02 *$ & $109.2 \pm 7.04 *$ & $100.2 \pm 8.242 *$ \\
\hline G.5: lead + DMSA + ALA & $148.4 \pm 6.2 * *$ & $66.80 \pm 4.81 * *$ & $60.91 \pm 4.467 * *$ \\
\hline
\end{tabular}

$\bullet$ Highly significant at $P<0.001$ compared to control (t- test).

* A significant at $\mathbf{P}<0.05$ compared to lead treated group (ANOVA).

** Highly significant at $\mathrm{P}<0.001$ compared to lead treated group (ANOVA).

Table (6): Serum kidney function tests in different rat groups

\begin{tabular}{|c|c|c|c|}
\hline Groups & $\begin{array}{c}\text { Urea }(\mathrm{mg} / \mathrm{dl}) \\
(\text { Mean } \pm \text { SE })\end{array}$ & $\begin{array}{c}\text { Creatinine (mg/dl) } \\
(\text { Mean } \pm \text { SE) }\end{array}$ & $\begin{array}{l}\text { Uric Acid }(\mathrm{mg} / \mathrm{dl}) \\
(\text { Mean } \pm \text { SE) }\end{array}$ \\
\hline G.1: control & $24.7 \pm 1.5$ & $0.351 \pm 0.01$ & $4.92 \pm 0.25$ \\
\hline G.2: lead only & $53.82 \pm 4.56^{\circ \bullet}$ & $0.554 \pm 0.044^{\bullet \bullet}$ & $7.875 \pm 0.48^{\bullet \bullet}$ \\
\hline G.3: lead + DMSA & $38.31 \pm 3.69 *$ & $0.417 \pm 0.016 *$ & $5.986 \pm 0.49 *$ \\
\hline G.4: lead + ALA & $40.64 \pm 3.75 *$ & $0.433 \pm 0.037 *$ & $6.175 \pm 0.46 *$ \\
\hline G.5: lead + DMSA + ALA & $28.82 \pm 2.43 * *$ & $0.356 \pm 0.014 * *$ & $5.1 \pm 0.25 * *$ \\
\hline
\end{tabular}

•• Highly significant at $\mathrm{P}<0.001$ compared to control (t- test).

* A significant at $\mathbf{P}<0.05$ compared to lead treated group (ANOVA).

** Highly significant at $\mathrm{P}<0.001$ compared to lead treated group (ANOVA). 


\section{DISCUSSION:}

Lead a common environmental and occupational toxic heavy metal (Leggett, 1993). The general population may get exposed to lead due to food and water contamination and air pollution caused by industrial emission and gasoline containing lead compounds (Ercal et al., 1996).

Lead induced free radical damage could result from disruption of heme biosynthesis leading to accumulation of delta-aminolevulonic acid dehydratase ( $\delta$-ALAD), direct interaction with biological membranes and induction of lipid peroxidation or indirect oxidative damage via $\delta$-ALAD generated reactive oxygen intermediate (Eracl et al., 1996).

Occupational and environmental exposure to lead has a significant impairment in the renal function of animals and human (Payton et al., 1994). The low environmental lead exposure cause renal impairment in children and adults (Burbure et al., 2003). Lead is known to produce oxidative damage in the liver tissues by producing peroxidation of membrane lipids (Chaurasia and Kar, 1997).

In the present study the blood lead concentration was increased after administration of lead acetate in drinking water in a dose of $0.2 \%$. DMSA was significantly effective in reducing the lead concentration from blood which coincide with the results of Hamidinia et al. (2006).

Also the current study demonstrated that ALA not decrease blood lead level which was in agreement with Patrick, (2006) who reported that administration of ALA was not effective in decreasing blood or tissue lead levels compared to the well-known chelator DMSA.

ALA was unable to mobilize lead concentration from blood suggesting it had no chelating property. However, a significant decrease in blood lead concentration after combined ALA plus DMSA administration points to a possibility that ALA acid might be facilitating the entry of strong lipophilic chelator like DMSA for an effective mobilization of brain lead (Pande, and Flora, 2002)

Treatment with DMSA may confer some degree of protection against lead-induced oxidative stress, as evidenced by an enhancement of the oxidized glutathione level and significant decline in MDA levels in the brain and liver tissue of lead-exposed mice. However, because DMSA is clearly an effective chelator, it remains unclear as to whether these results are attributable solely to DMSA potential to serve as a thiol antioxidant rather than its ability to rid tissue of lead and thereby decrease the prooxidant threat. The antioxidant action of DMSA when compared to the results obtained from groups treated with the antioxidant $\mathrm{N}$-acetyl cysteine is less effective (Ercal et al., 1996).

Combination of ALA and DMSA in leadexposed animals was more effective than either used alone in preventing oxidative damage (Sivaprasad et al., 2004b).

In the present study there was a significant increase in the lipid peroxidation in lead treated group. This was in agreement with Caylak et al., (2008) and Ercal et al. (1996).

In the present study ALA is capable of diminish lipid peroxidation which was determined by estimating serum MDA level which coincide with the results of Gruer $e t$ al., (1999).

In agreement with the present study Sivaprasad et al., (2002) who mentioned that when ALA used without a chelator had a significant ability to prevent lipid peroxidation in the kidneys of lead-exposed rats, but when 
DMSA was added to ALA, the combined effect was even greater.

Serum (or plasma) concentrations of different antioxidants can be measured in laboratories separately, but they are timeconsuming, labor-intensive, costly, and require complicated techniques. So measurement of the total antioxidant capacity or status of a sample is preferred (Tsai et al., 1994 and Erel, 2004).

The present study revealed presence of significant decrease in the serum total antioxidant level in lead treated group. This was in agreement with Hsu, (1981) who reported that the levels of antioxidant enzymes such as superoxide dismutase, catalase, and glutathione reductase were decreased in lead-exposed rats and level of the reduced glutathione was strongly correlated with lead intoxication.

Also the present study coincide with Sivaprasad et al., (2003) who reported that rats exposed to lead in drinking water for 5 weeks was showed lowered activities of catalase, superoxide dimutase, glutathione perioxidase and reduced glutathione. Besides, Ercal et al. (1996) who mentioned that mice exposed to lead in drinking water for 5 weeks showed decrease glutathione level.

In the present study treatment with ALA either alone or in combination with DMSA resulted in reversal of the decreased serum total antioxidant level and the effect was more effective with combined treatment with DMSA. This was in agreement with and Sivaprasad $e t$ al., (2003)

ALA and DHLA resulted in significant improvement in of thiol capacity of cells via increasing glutathione levels and decreasing malondialdhyde levels in lead exposed cells and animals indicating a strong shift of lead induced oxidative stress (Gruer et al., 1999).

ALA and DHLA are ideal antioxidant because of their several properties: (1) they have ability to scavenge some reactive species (2) they can regenerate other antioxidants such as vitamins $E$ and $C$ and reduced glutathione (GSH) from their radical or inactive forms (4) Both have metal chelating activity (Biewenga $e t$ al., 1997).

In the present study the serum NO level was highly significantly decreased in lead treated group. This was in agreement with Heydari, et al., (2006) who mentioned that lead administration in rats in 4,8 , and 12 weeks resulted in decrease serum NO level which may attributed to either decreased NO production or enhanced NO inactivation by free radical formation. Also coincide with (Vaziri et al., 1997) who reported that glutathione depletion and lead exposure have been independently shown to depress nitric oxide in animal models.

Improvement in serum NO level after ALA administration because it is an antioxidant that functions to replenish glutathione and vitamins $\mathrm{C}$ and $\mathrm{E}$, reduce lipid peroxides, scavenge free radicals and chelate toxic metals (Packer et al., 1995).

In animal studies exploring its effect in lead toxicity, ALA acid had no direct chelating ability but was consistent in countering the effects of lead on hepatic and renal glutathiones and oxidative stress markers (Pande, and Flora, 2002 \& Sivaprasad et al., 2002).

In the present study lead administration resulted in increase serum alkaline phosphatase (ALP), serum glutamic oxalacetic transaminase (GOT) and serum glutamaic pyruvic transaminase (GPT or ALT). This is because lead is known to produce oxidative damage in the liver tissues by producing peroxidation of membrane lipids. These enzymes are markers of liver injury (Chaurasia and Kar, 1997). Lead cause derangement of several hepatic biochemical pathways and energy metabolism (Taki et al., 1985). 
In the current study treatment with DMSA or ALA improved the increased hepatic enzyme levels and this improvement was highly significant when ALA and DMSA were given in combination. This coincide with Shalan et al. (2005) who mentioned that administration of lead acetate in diet for 6 weeks resulted in elevations of serum GPT, GOT, and ALP. Administration of vitamin $C$ with lead acetate three times/week orally as an antioxidant showed improvement of biochemical finding.

The usefulness of the antioxidant $L A$ in conjunction of DMSA was effective in rebalancing the impaired prooxidant/ antioxidant ratio. Exogenous administration of ALA and DMSA separately brought about an improvement in the cells antioxidant defense armory due to their antioxidative property (Packer et al., 1995 and Gurer and Ercal, 2000).

Lead cause nephropathy reported in many experimental studies. The severity of renal lesion depends on the animal species (Vyskocil et al., 1989).

In the present study leads administration resulted in increased the serum urea, serum ceratinine and serum uric acid. Treatment with DIMSA and ALA significantly improved the increased biochemical parameters of kidney toxicity. The combination of ALA and DMSA showed effective improvement in these parameters to normal levels. This coincide with the results of Sivaprasad $e t$ al (2002 and 2004a) who mentioned that administration of lead acetate in drinking water to male rats for 5 weeks resulted in the increased gammaglutamyl transverase and $\mathrm{N}$-acetyl beta-Dglucosaminidase in rat kidney and the combination of ALA and DMSA resulted in improvement of the renal tubular defects.

In agreement with the present study the urinary excretion of nitrogenous waste products and creatinine in lead poisoned patients with chronic renal disease due to impaired transport in the proximal renal tubules which corrected by chelation therapy (lin et al., 2001). Also the increased lead excretion and improvement in the metabolic indices (erythrocyte $\gamma$-ALA dehydratase) in human workers after DMSA therapy (Graziano et al., 1985).

The assessment of renal integrity following combined therapy with ALP and DMSA showed marked improvement with respect to the enzyme activities thus indicating the membrane stabilizing effect of ALA (Packer et al., 1995) and antinephroscelrotic action of DMSA (Graziano et al., 1985)

The basic mechanism underlying the nephroprotection of ALA and DMSA may involve chelation with lead prior to its interaction with the cellular sites and /or maintenance of membrane integrity by providing endogenous sulphydryl group (Sivaprasad et al., 2004a).

Generally the effect of combination therapy was better than the monotherapy, in effective turnover of oxidative stress as the antioxidant ALA scavenge the free radicals and facilitate entry of DMSA to different organs including the brain as it cross the blood brain barrier (Pande and Flora, 2002).

\section{CONCLUSION AND RECOMMENDATION:}

Consequently, the supplementation of ALA as a sulpher (thiol) containing antioxidant may be beneficial in occupationally exposed workers to chronic low doses of lead in industries such as in paints, glass, ceramic, batteries, pigments, and welding. It is advised to be given with chelation treatment protocols for lead toxicity as it may have positive therapeutic implications. 


\section{REFERENCES:}

Adonaylo, V.N., Delpour, A.R. and Oteiza, P.I. (1999): Lead intoxication: antioxidant defenses and oxidative damage in rat brain. Toxicol., 135:77-85.

Biewenga, G.P., Haenen, G.R.M. and Bast, A. (1997): The pharmacology of the antioxidant lipoic acid. Gen. Pharmacol. 29: 315-331.

Boeckx, R.L. (1986): Lead poisoning. Anal. Chem. (58): 273-287.

Burbure, C., Buchet, J.P., Bernard, A., leroyer, A., Nisse, C., Haguenoer, J.M., Beramaschi, E. and Mutti, A. (2003): Biomarkers of renal effectsin children and adults with low environmental exposure to heavy metals. J. Toxicol. Environ. Health, 66:783-798.

Chaurasia, S. and Kar, A. (1997): Protective effects of vitamin $E$ against lead induced destruction of membrane associated typeI iodothyronine 5'-monodeiodinase (5'DI) activity in male mice. Toxicol. 124: 203209.

Coulombe, J. and Favreau, L. (1963): A new simple semimicro-method for colorimetric determination of urea. Clin. Chem., 9: 102-108.

Cyalak, E., Aytekin, M. and Halifeoglu, I. (2008): Antioxidant effects of methionine, alpha-lipoic acid, $\mathrm{N}$-acetylcysteine on lead induced oxidative stress to erythrocytes in rats. Exper. Toxicol .Pathol., 60 (4-5) 289-294.

Delpour, A.R., Essalat, M., Ala, S. and GhaziKhansari, M. and Ghafori, P. (1999): Increase by NO synthese inhibitor of lead-induced release of $\mathrm{N}$-acetyl-beta-Dglucosaminidase from perfused rat kidney. Toxicol., 132:119-125.
Ercal N., Gurer-Orhan H. and Aykin-Burns, N. (2001): Toxic metals and oxidative stress. Part1. Mechanisms involved in metalinduced oxidative damage. Curr. Top. Med. Chem.;1:529-539.

Ercal, N., Treeratphan, P., Hammond, T.C., Richard, H., Matthews, R.H., Grannemann, N.H. and SPITZ, D.R. (1996): In vivo indices of oxidative stress in lead-exposed C57B1/6 mice are reduced by treatment with meso-2,3dimercaptosuccinic acid or $\mathrm{N}$-acetyl cysteine, Free Radical Biol. Medicine, 21(2): 157-161.

Erel, O. (2004): A novel automated direct measurement method for total antioxidant capacity using a new generation, more stable ABTS radical cation. Clin. Biochem., 37: 277-285.

Goyer, R.A. and Chirian, M.G. (1979): Treatment of lead toxicity. 24:433-443.

Green, L.C., Wagner, D.A., Glogowski, J., Skipper, P.L., Whishnok, J.S. and Tannenbaum, S.R. (1982): Analysis of nitrate, nitrite and [15N] in biological fluids. Ann. Biochem.; 126: 131-138.

Graziano, J.H., Siris, E.S. and Lolacono, N. (1985): 2,3-Dimercaptosuccinate as an antidote for lead intoxication. Clin. Pharmacol. Ther. 37: 431-438.

Gurer, H. and Ercal, N. (2000): Can antioxidants be beneficial in the treatment of lead poisoning? Free Radic. Biol. Med. 29: 927-945.

Gurer, H., Ozgunes, H., Neal, R., Spitz, D. R. and Ercal, N. (1998): Antioxidant effects of $\mathrm{N}$-acetylcysteine and succimer in red blood cells from lead-exposed rats. Toxicol., 128:181-189.

Gurer, H., Ozgunes, H., Oztezcan, S. and Ercal, N. (1999): Antioxidants role of lipoic acid 
in lead toxicity. Free Radic. Biol. Med., 27 (1-2):75-81.

Hamidinia, S.A., Erdahl, W.L., Chapman, C. J., Steinbaugh, G.E., Taylor, R.W. and Pfeiffer, D.R. (2006): Manesin improves the effectiveness of mesodimercaptosuccinate when used to treat lead intoxication. Enviorn. Health Perspect. 114(4): 484-493.

Heydari, A., Norouzzadeh, A., Khoshbateen, A., Asgari, A., Ghasemi, A., Najafi, S. and Badalzadeh, R. (2006): Effects of short term and subchronic lead poisoning on nitric oxide metabolites and vascular responsiveness in rat. Toxicol. Letters, 166 (1): 88-94.

Hsu, J. M. (1981): Lead toxicity related to glutathione metabolism. J. Nutr. 111: 2633.

Larsen, K. (1972): Creatinine assay by a reaction-kinetic principal. Clin. Chem. Acta, 41: 209-217.

Leggett, R.W. (1993): An age-specific kinetic model of lead metabolism in humans. Environ. Health. Perspect. 101: 598-616.

Lima-Hermes, M.; Pereira, B. and Bechara, E. J. H. (1991): Are free radicals involved in lead poisoning? Xenobiotica 21: 10851090.

Lin, J.L., Yu, C.C., Lin-Tan, D.T. and Ho, H.H. (2001): lead chelation therapy and ureate excretion in patients with chronic renal diseases and gout. Kidney Int., 60: 266271.

Lockitch, G. (1993): Perspectives on lead toxicity. Clin. Biochem. 26:371-381.

Miller, L. (1998): Dimercapto-succinic acid (DMSA) a non-toxic, water-soluble treatment for heavy metal toxicity, Altern. Med. Rev., 3: 199-207.

Miller, N.J., Rice-Evans, C., Davies, M.J., Gopinathan, V. and Milner, A. (1993): A novel method for measuring antioxidant capacity and its application to monitoring the antioxidant status in premature neonates. Clinical Science; 84: 407-412.

Moini, H., Packer, L. and Saris, N.L. (2002): Antioxidant and Prooxidant Activities of Lipoic Acid and Dihydrolipoic Acid. Review. Toxicol. Appl. Pharmacol., 182: 84-90.

Packer, L., Weitt, E.H. and Tritcher, H.J.(1995): Alpha-lipoic as a biological antioxidant. Free Radic. Biol. Med. 19: 227-250.

Pande, M. and Flora, S. J. S. (2002): Lead induced oxidative damage and its response to combined administration of lipoic acid and succimers in rats. Toxicol., 177: 187-196.

Packer, L., Witt E.H. and Tritschler, H.J. (1995): Alpha-lipoic acid as a biological antioxidant. Free Radic. Biol. Med., 19:227-250.

Patrick, L. (2006): Lead toxicity, Part II: The role of free radical damage and the use of Antioxidants in the pathology and treatment of lead toxicity. Altern. Med. Rev., 11(2): 114-127.

Payton, M., Hu, H., Sparrow, D. and Weiss, S.T. (1994): Low level lead exposure and renal function in the normative aging study. Am. J. Epidemiol., 140: 821-829.

Reitman, S. and Frankel, S. (1957): Colorimetric method for the determination of GOT and GPT. Am. J. Clin. Pathol., 28:58-61.

Shalan, M.G., Mostafa, M.S. Hassouna, M.M., El-Nabi, E.E. and El- Refaie (2005): Amelioration of lead toxicity on rat liver with vitamin $C$ and silymarin supplements. Toxicol., 206(1): 1-15.

Sivaprasad, T.R., Malarkodi, S.P. and Varalakshmi, P. (2004a): Therapeutic 
efficacy of lipoic acid in combination with dimercaptosuccinic acid against leadinduced renal tubular defects and on isolated brush-border enzyme activities. Chem.Biol. Interact., 147: 259-271.

Sivaprasad, T. R., Nagaraj, M. and Varalakshmi, P. (2004b): Combined efficacies of lipoic acid and 2,3dimercaptosuccinic acid against leadinduced lipid peroxidation in rat liver. $\mathbf{J}$. Nutr. Biochem., 15:18-23.

Sivaprasad, T.R., Nagaraj, M. and Varalakshmi, P. (2002): Lipoic acid in combination with a chelator ameliorates lead-induced peroxidative damages in rat kidney. Arch. Toxicol., 76(80): 437-441.

Sivaprasad, T.R., Nagaraj, M. and Varalakshmi, P. (2003): Combined efficacies of lipoic acid in combination with 2,3-dimercaptosuccinic acid on leadinduced erythrocyte membrane peroxidation and antioxidant status in rats. Hum. Exp. Toxicol., 4: 183-192.

Spitz, D.R., Sullivan, S.J., Malcolm, R. and Roberts, R.J. (1991): Glutathione dependent metabolism and detoxification of 4-hydroxy-2-nonenal. Free Radic. Biol. Med. 11: 415-423.

Taki, Y. Shimahara, Y. and Isselhard, W. (1985): Derangement of hepatic injury metabolism in lead-sensitized endotoxicosis. Eur. Surg. Res.,17:140-149.
Thayer, W. (1984): lipid peroxide in rats treated chronically with adriamycin. Biochem. Pharmacol.; 33(14):2259-2263.

Tietz, N.W. and Rinker, A.D. (1983): The measurement of alkaline phosphatase. In: Analytical Concepts in Enzymology. Homberger, H.A. (Ed.), College of American Pathologists, P.P. 195-203.

Tsai, E.C., Hirsch, I.B., Brunzell, J.D. and Chait, A. (1994): Reduced plasma peroxyl radical trapping capacity and increased susceptibility of LDL to oxidation in poorly controlled IDDM. Diabetes; 43: 1010-1014.

Whitehead, T.P., Bevan, E.A. and Leonardi, A. (1991): Defects in diagnostic kits for determination of ureate in serum. Clin. Chem., 37(6): 879-881.

Vaziri, N. D., Ding, Y., Ni, Z. and Gonick, H. C. (1997): Altered nitric oxide metabolism and increased oxygen free radical activity in lead-induced hypertension: effect of lazaroid therapy. Kidney Int.; 52: 10421046.

Vyskocil, A., Pancl, J., Miloslav, T., Ettlerova, E., Semeky, V., Kasparova, L., Lavwerys, R. and Bernard, A. (1989): Dose-related proximal tubular dysfunction in male rats chronically exposed to lead. J. Appl. Toxicol., 9:395-399. 
التأثير العلاجي لحامض الألفاليبوك عند إضافته للسكسمر المضاد للجهد المؤكسد والتسمم الكبدي و الكلوي للرصاص في الجرذان

خالد حمه عبد العال"، عبير حمد رشاد حسين *قسم الطب الثرعي والسموم الإكلينيكية، **قسم الفارماكولوجى

كلية الطب - جامعة أسيوط

يعتبر التسمم بالرصاص مشكلة صحية في كل دول العالم لتأثيره على عديد من أجهزة الجسم وخاصة الكبد

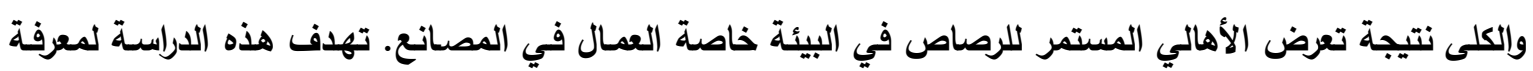

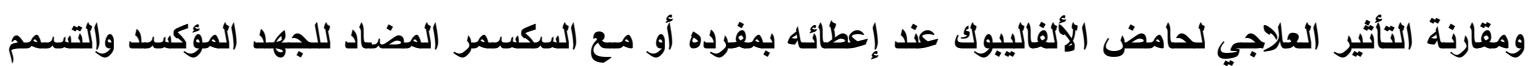
الكبدي وإلكلوي للرصاص في الجرذان البيضاء.

قد أجريـت هذه الدراسـة على ه V مـن ذكـور الجرذان البيضـاء البالغـة السليمة التي قسمت إلى خمسـة



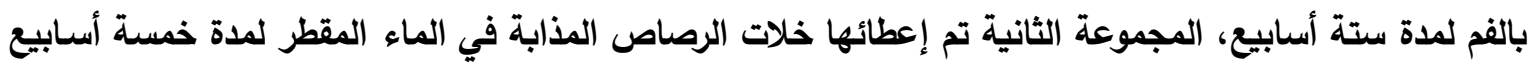

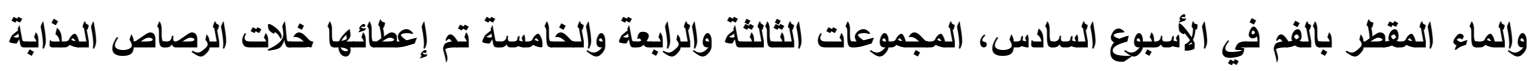



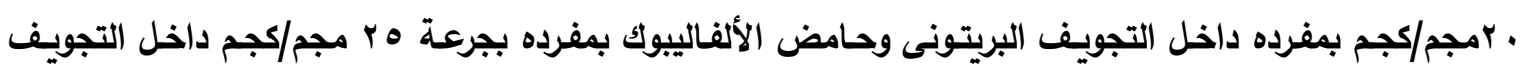

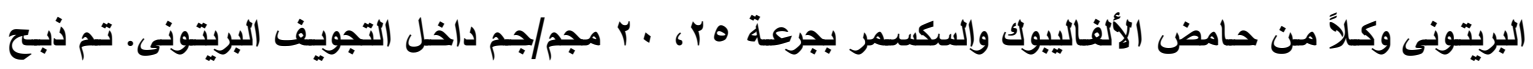
الجرذان في نهاية الأسبوع السادس وأخذت عينات الدم لقياس مستوى الرصاص بالات ولام ومستوى ومؤشرات الجها

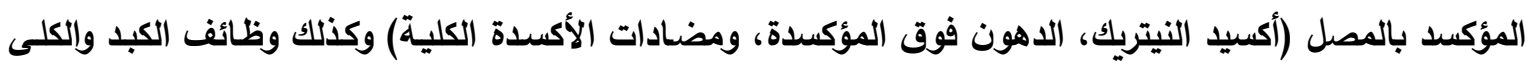

أوضحت نتائج الدراسة ارتفاع مستوى الرصاص بالدم ومؤشرات الجهد المؤكسد ووظائف الكبد وإلكلى في

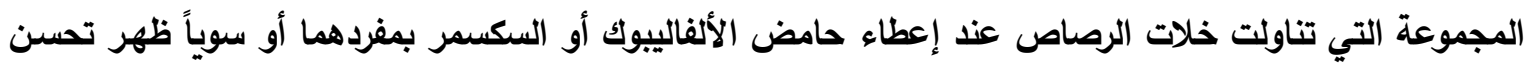

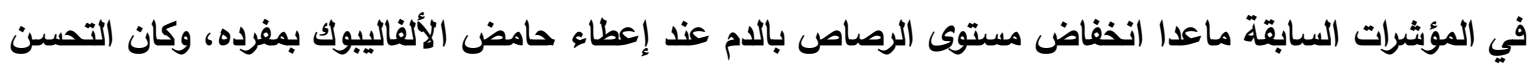
أكثر وضوحاً عند إعطائهما سوياً .

ويستخلص من هذه الاراسة أن إعطاء حامض الألفاليبوك بمفرده أو مع السكسمر لله تأثير مفيد في تحسن

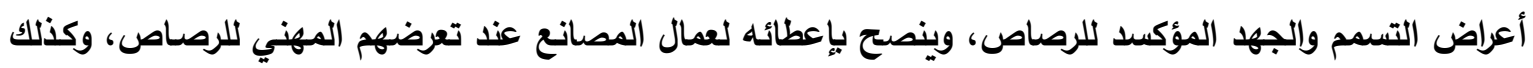
في النظام العلاجي لحالات التسمم بالرصاص مـع السكسمر حيث يزيل من فاعليته. 